\title{
Rebranding Ukrainian Generations and Generation Y through the Prism of Modern Views
}

\author{
Anatoliy Kuzminskyy* \\ Bohdan Khmelnytskyy National University of Cherkasy, Ukraine \\ *Corresponding author: ntaras7@ukr.net
}

Received September 29, 2014; Revised October 23, 2014; Accepted December 14, 2014

\begin{abstract}
The article offers a short survey of the Ukrainian generations of 1900 through 2000. It details on the main features of the epoch and the environment in which generation $Y$ was formed. The author specifies on the generation born in $1983-2003$ and connects it with the peculiar features of the "millennials" entry into higher education.
\end{abstract}

\section{Keywords: generation Y, formation, Millennial Students, higher education}

Cite This Article: Anatoliy Kuzminskyy, "Rebranding Ukrainian Generations and Generation Y through the Prism of Modern Views." American Journal of Educational Research, vol. 2, no. 12B (2014): 83-86. doi: 10.12691/education-2-12B-15.

\section{Introduction}

Problem of generations has been among the main fields of interest for many renowned thinkers of the world, beginning with Socrates, who was one of the first to raise this issue and, in particular, severely criticized the young generation contemporary to him. For centuries youth used to be treated mostly critical and skeptical. These debates do not cease today.

US scientists - economist and sociologist Neil Howe and historian and writer William Strauss in the early nineties developed a theory of generations and tried to find out what the very concept of a "generation" is, what is the most objective and appropriate way to classify different generations, and what the essence of the phenomenon of conflict of generations is. The research of the aforementioned scholars was based mainly on the US experience and data. On analyzing the situation of the period from 1584 to 1991 they made the forecast up to 2069 and described five generations of the XXth century. They employed the American data, the data and experience of some other countries, and the data from the life of the former Soviet Union.

Conflict of generations in Ukraine as part of Tsarist Russia before 1917 and that of the country as one of the republics of the USSR from 1917 to 1991, and in the period starting in 1991 when Ukraine became an independent and sovereign state are three different conflicts.

The G.I. Generation, or as it is called "the Greatest Generation", "generation of winners" are the people who were born in the years 1900-1923 and their formation and socialization took place before 1933. The significant events of the period: two revolutions of 1905 and 1917, the first world war, civil war, brutal totalitarian regime with its transformational processes: forced collectivization, repression, starvation told on the formation of this generation in Ukraine. Fear, insecurity, ideological offishness, vain expectations of a better future are among the main characteristic features of the majority of the representatives of that generation. Such inherently Ukrainian traits as diligence, great performance, patience and being law-abiding contributed to the rapid development of the recovery of national economy, industrialization, the rise of culture. However, the Ukrainian "G.I. generation " fully felt all the "charms" of the inhuman socialist system - poverty, repressions, ethnic oppressions, "Executed Renaissance" in the cultural and spiritual realm up to the artificial famine of 1932-1933, which claimed millions lives and that actually was a genocide of the people of Ukraine by the ruling elite of the Soviet Union.

In the years 1923-1943 the "silent generation" (also known as the "Lucky Few") was being born. The period of its formation lasted until 1953. N. Howe and W. Strauss believe that this human grading is characterized by tolerance and respect for the law. In Ukraine, the representatives of this generation were under the influence of famine and repressions of the thirties, terrible realities of the Second World War, and the difficulties of the postwar reconstruction. The famine of 1947-1948 also had its effect.

Strict observance of laws based on fear, forced commitment to the dominant ideology, attempts to achieve the highest possible social status were the features of this generation.

The generation which was born in the years 1943-1963 and accordingly formed until 1973, is called "the turbulent generation" or "the generation of baby-boomers". This is due to the significant baby boom during this period. The people of this generation lived in the environment of intense work, the Cold War, the threat of nuclear 
apocalypse. Among the positive factors of the period one can mention the so-called 'Khrushchev thaw', the achievements of the USSR in space exploration, some tendency to improve housing. This generation is marked by the spirit of collectivism, that was strongly encouraged by the current authoritarian regime, by the attempts to achieve career growth, and certain social optimism.

In the years 1960-1983 generation "X" or "the Unknown Generation" was born. Its formation was until 1993. The growth of national consciousness, desire for national independence (which came in 1991), Gorbachev's perestroika, the spread of dangerous diseases with the AIDS among them, alcoholism, and drug-addiction of a significant pert of the youth were the characteristic features of the Ukrainian life in that period.

There took place a gradual shift from the prevailing doctrine of collectivism to the realization by many people of the idea that they are self-contained and free subjects of social and political life. People got more informed and intelligent, felt the necessity of better education, especially of life-long education.

\section{Discussion and Results}

The generation which is now the biggest concern is the people born in 1983-2003. The ideas of different authors as to the characteristics of this generation both on the global as well as on the local scales are quite diverse, and sometimes, controversial. And this is one of the reasons why this generation has so many names. It is called "the millennium generation", "generation-next", "netgeneration", "generation Y", etc. The term "generation Y" is the one that is the most widely exploited and we use it here.

What were those factors that significantly influenced the formation of generation Y in Ukraine? First of all, it's Ukraine's independence as a result of the collapse of the Soviet Union. Global informatization, painful transition from the administrative command economic system to a market economy, the fact that public life got partially free from being excessively politically and ideologically set and public relations became more liberal and humane, the introduction of paid forms of education are also among the important factors.

There are two views on the significance of the influence of the previous generation on the attitudes and values of the next one. According to the first view the parents are trying to raise their children in the context of the values that are common and important to them. On the other hand, the parents want to create the environment for their children which would be dramatically different from the one into which they had been born and in which they themselves were raised. They want the lives of their children to be qualitatively different from their own lives. The psychology formed by the parents according to their philosophical principles and commitment to the values that they could not use in their lives is the peculiar feature of the Ukrainian generation Y. And we can't but mention the influence of the environment and those global and local events against the background of which this generation grew and matured.

The main characteristic feature of the influence of "generation $\mathrm{X}^{\prime}$ on "generation $\mathrm{Y}$ " in Ukraine is that parents try to provide their children with the University education and, preferably - liberal education. The competition for being enrolled for economic, legal, educational, and medical profile specialties is rather severe. And those Universities that take students for technical, natural and mathematical, agricultural specialties experience serious problems with competitive admission.

Our studies show that secondary education in Ukraine witnesses the reduction of interest and quality of knowledge in mathematics, physics, chemistry, and biology.

A characteristic feature of a large part of the Ukrainian "millennials" is their excessive demands on their own sustenance: "I want a lot and immediately". In the routine of everyday life, they put personal needs and interests above the public ones. But as the practice of the last period shows, in the force majeure situations, a significant portion of the Igreks dramatically change the orientation from self-centered to patriotic, often sacrificing their health and their lives defending the independence and interests of their homeland. It was these 18-22-year-old students and young people who became the generators and participants' of the "Dignity revolution" of 2014 in Ukraine. Many of those who are fighting terrorists in eastern Ukraine, and dying for freedom, independence and integrity of the state are the young people born in the 8090 s of the previous century.

Even though the background, which was the formation of "Generation X" and "Generation Y" is largely the same, the distinctive feature of the period of socialization of

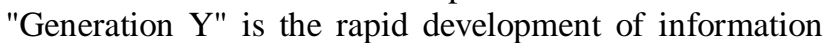
technology, the wide spread of the Internet, and the use of various gadgets. The Igreks are characterized by a significantly decreased interest in books, communicating in real life. It is not by chance that contemporary 20-30 year old people are often called "the net-generation". The Ukrainians of this age are often marked by the insufficient knowledge of real life; they are often naive and even infantile, with the males' positions being inferior.

The period of the formation of the generation Y's in Ukraine there were rapid changes in economics, politics, and culture. The socialist economy was being superseded by the market economy. The laws related to making money became more liberal. There appeared cooperatives, private enterprises and other forms of manufacturing and service. Trade barriers were removed. What was once called profiteering and used to be severely persecuted became a legal way of making money. There opened the opportunities to travel abroad for private commerce and selling the Ukrainian goods, and to privately import foreign goods which were in short supply in Ukraine for sale. A significant portion of the parents of 'generation $\mathrm{Y}$ ' became the so-called "shuttle vendors". A large sector of the economy went to private ownership and the new owners dictated new and largely unfamiliar job terms and conditions to the jobseekers, with the increasing share of the representatives of 'generation $\mathrm{Y}$ ' among the latter.

The dominance of the social policy of collectivism suffered crashes. Young people are increasingly unwilling to work in a team for the common good and are more and more often looking for opportunities to work individually, "for oneself", or at least in a group of their peers of similar mentality and world view. 
Unlike the previous generation the Ukrainian Igrekgeneration increasingly preferred an individualistic lifestyle.

Lifestyle of the previous generations which was based on the principle "to live for the sake of work", was being substituted by the formula "to work for the sake of living, and living should be as comfortable as possible". This transformation became possible as a result of the elimination of "the iron curtain", the convergence with the developed European and North American countries, and the processes of totalitarian globalization.

As for the practical work, the motivation for it in the Igreks is quite different than that of their parents. They seek a meaningful work which should be creative, interesting for them, and promising in terms of career. Even the payment is not the main incentive. The Igreks are not attracted by traditional jobs. They prefer working with the latest technology and modern means of communication.

Work, public activities, social values, and interests ("first think of your motherland and only then think of yourself") were the main priorities for the parents of the generation of the "millennials", but for the "millennials" themselves, the thing which is of primary importance is their personal life. The Ukrainian Igreks start their family life later than their predecessors. Family values and relationships are more significant for them.

Sometimes the Ukrainian "millennials" are considered insufficiently socially responsible and binding, and even lazy. But the studies show that it is not so. 10 to 20 percent of university graduates of an educational qualification of "specialist" ("expert") and "master" receive diplomas with honors, that demonstrates a high level of knowledge and competence. The "millennials" who are employed are maximalists, they seek selfactualization at work, getting adequate remuneration for their work, and prefer flexible working hours, looking for the most appropriate means and methods of performing the production tasks. Unlike their parents, who appreciate their office and reluctantly change the jobs even if they are not satisfied with the latter, the "millennials" are more flexible in this respect and they easier change jobs if they do not meet their demands and needs.

The "millennials" views on life and human relationships are more liberal and democratic than those of their parents. The majority of the young people prefer civil marriage, they are entering sexual relations in a much younger age than their parents, the Igreks are more comfortable with gay marriage, though the last is not that usual in Ukraine.

A modern Ukrainian student of the millennium generation is gadgets-friendly and for them the Internet has become a reference, a manual, and an Encyclopaedia.

As of now the share of a student's independent work has been dramatically increased in the training process. The role of the teacher and the time of their direct involvement in students' education has significantly reduced of late. The teacher's function is that of a tutor, facilitator, advisor, consultant who is planning and developing training objectives for the student, providing the necessary techniques for their implementation, and who performs control functions without a direct participation in the students' learning activities.
A Ukrainian student of nowadays becomes more demanding to the teacher's or instructor's professional and personal qualities. A student is impressed by the teacher who is a bright knowledgeable, and erudite personality, who can interest students and build relationships with them on the subject-to-subject basis. The latter is particularly important in view of the fact that the Ukrainian system of education, which has long been an integral part of the Soviet educational system, was dominated by the subject-object format of relations between teacher and student. The rudiments of this form of relationship are often a cause of confusion and conflict between the participants of the educational process.

As the result of the globalization processes, the Ukrainian Igreks pay more and more attention to learning foreign languages as a means of mobility, opportunity to build a career not only in Ukraine, but also abroad. The admission to the schools of philology in the Universities is very competitive as it means new perspectives and new chances. But the number of those whose ambitions are realized from the very first try is not that high. Moreover, many of the "millennials" do not persist in keeping trying.

It should be noted that when we talk about this or that distinguishing feature of "generation $\mathrm{Y}$ ", we mean those most frequently displayed features and qualities which are characteristic for the majority of their representatives. In fact, the dominant life principles, worldview, social behavior, life trends of different layers of the Igreks are dramatically different. They depend on many factors economic, social, political, and geographical. For example, the young people of the Western Ukraine stand out as devoutly religious. Young people from central Ukraine and the western parts of the country clearly show their adherence to national traditions and more often display their national dedication. Urban Igreks have more opportunities for education, better job placements, the organization of leisure, and so on.

The most common features, characteristics and trends of different generations are in many respects similar or even common to the whole of human civilization of a certain age. The first four generations of Ukraine of the XXth century were largely dependent on external factors and circumstances. The dependence on other countries, revolutions, wars, social and technological upheavals, domination of the totalitarian and authoritarian regimes left a significant imprint on the consciousness, social, psychological, and spiritual characteristics of these generations. Psychological rigidness, depression, fear, poverty, isolation from world civilization processes, and the low level of national consciousness are the most common characteristics of the Ukrainian generations of 1900-1980.

\section{Conclusions}

It is natural that "generation Y" couldn't but inherit from their predecessors - the previous four generations certain features and properties, especially - from their parents who represented "generation X". But the impact of globalization and localization processes, scientific and technological progress, a significant change in socioeconomic conditions, the creating of their own statehood 
left a significant imprint on the formation, ideology and worldview of the "millennium" generation.

Thus, the current "Y-generation" resembles the previous one only in some features. The gap in mentality, worldview, information awareness between the Igreks and their parents' generation is much bigger than between/among all the previous generations.

The characteristic features of a significant part of the Ukrainian "net-generation" are the absence of ideological and political engagement, freedom and critical thinking, prevailing of the individualistic interests over the collectivist ones, wide information and informative literacy, the desire to master a foreign language, find interesting, creative and well-paid work, and organize their education in some developed country where higher education is the most versatile and flexible higher education system for international students in the world and then, by chance, to seek employment and residence there. They have the capacity for greatness, indeed.

Time will show what "generation $Y$ " will pass to "generation Z", which is born and formed now, and what this unknown generations will appear to be.

\section{References}

[1] Grenier, A. Crossing age and generational boundaries: Exploring intergenerational research encounters, Journal of Social Issues 63 (4): 718, 2007, Available: http://onlinelibrary.wiley.com/doi/10.1111/j.1540-
4560.2007.00532.x/abstract;jsessionid=FA4114020A67ED770547 C114ABF1E757

[2] Hoover, E. (11 October 2009), "The Millennial Muddle". The Chronicle of Higher Education. Retrieved 12 August 2014, Available: http://chronicle.com/article/The-Millennial-MuddleHow/48772.

[3] Horovitz, B. (May 4, 2012). After Gen X, Millennials, what should next generation be?, USA Today. Retrieved August 16, 2014, Available: http://usatoday30.usatoday.com/money/advertising/story/2012-0503/naming-the-next-generation/54737518/1.

[4] Hunt, Tristram (2004-06-06). One last time they gather, the Greatest Generation, The Observer (London). Retrieved: August 16, 2014, Available: http://www.theguardian.com/uk/2004/jun/06/secondworldwar.

[5] Huntley, R. Political parties ignore Generation Y at their own peril, Available: http://www.onlineopinion.com.au/view.asp?article=2568.

[6] Jones, L. Great Expectations: America and the Baby Boom Generation. New York: Coward, McCann and Geoghegan, 1980.

[7] Mannheim, K. The problem of generation, in K. Mannheim, Essays on the Sociology of Knowledge, London: RKP, 1952.

[8] Strauss, William \& Howe, Neil. Generations: The History of America's Future, 1584 to 2069. Perennial, 1992. (Reprint), P. 324.

[9] Strauss, William \& Howe, Neil (1991). Generations. New York, NY: Harper Perennial. p. 318. Available: http://www.lifecourse.com/.

[10] Ulrich, J. Introduction: A (Sub) cultural Genealogy. In Andrea L. Harris. GenXegesis: essays on alternative youth. P. 3. Available: http://books.google.com.ua/books?id=v10ZUR.

[11] Williams, R. Is Gen Y Becoming the New "Lost Generation?. Wired for Success. Available: http://www.psychologytoday.com/blog/wired-success/201304/isge. 